\title{
SUBADDITIVE INEQUALITIES FOR OPERATORS
}

\section{Hamid Reza Moradi, Zahra Heydarbeygi and Mohammad Sababheh}

Abstract. In this article, we present a new subadditivity behavior of convex and concave functions, when applied to Hilbert space operators. For example, under suitable assumptions on the spectra of the positive operators $A$ and $B$, we prove that

$$
2^{1-r}(A+B)^{r} \leqslant A^{r}+B^{r}, \quad \text { for } r>1 \text { and } r<0,
$$

and

$$
A^{r}+B^{r} \leqslant 2^{1-r}(A+B)^{r}, \quad \text { for } r \in[0,1] .
$$

These results provide considerable generalization of earlier results by Aujla and Silva. Further, we present several extensions of the subadditivity idea initiated by Ando and Zhan, then extended by Bourin and Uchiyama.

Mathematics subject classification (2010): 47A63, 47A64, 47B65, 15A60.

Keywords and phrases: Operator inequality, operator convex functions, positive operator.

\section{REFERENCES}

[1] T. ANDO AND F. HiAi, Operator log-convex functions and operator means, Math. Ann. 350, 3 (2011), $611-630$

[2] T. ANDO AND X. ZHAN, Norm inequalities related to operator monotone functions, Math. Ann., 315 (1999), 771-780.

[3] J. S. AUJLA, Some norm inequalities for completely monotone functions, SIAM J. Matrix Anal. Appl., 22, 2 (2000), 569-573.

[4] J. S. Aujla AND F. C. Silva, Weak majorization inequalities and convex functions, Linear Algebra Appl., 369 (2003), 217-233.

[5] R. Bhatia, Matrix analysis, Springer-Verlag, New York, 1997.

[6] J. C. BOURIN AND M. UChIYAMA, A matrix subadditivity inequality for $f(A+B)$ and $f(A)+f(B)$, Linear Algebra Appl., 423 (2007), 512-518.

[7] S. S. DRAGOMIR, Hermite-Hadamards type inequalities for operator convex functions, Appl. Math. Comput., 218, 3 (2011), 66-772.

[8] T. Furuta, J. MićIĆ, J. PeČArić And Y. Seo, Mond-Pečarić method in operator inequalities, Inequalities for Bounded Selfadjoint Operators on a Hilbert Space, Element, Zagreb, 2005.

[9] I. H. GÜMÜsş, H. R. MorAdi AND M. SABABHeH, More accurate operator means inequalities, J. Math. Anal. Appl., 465 (2018) 267-280.

[10] M. Kian AND S. S. DRAGOMIR, $f$-Divergence functional of operator log-convex functions, Linear Multilinear Algebra, 64, 2 (2016), 123-135.

[11] J. MićIĆ, Z. PAVIĆ AND J. PEČARIĆ, Jensen's inequality for operators without operator convexity, Linear Algebra Appl., 434, 5 (2011), 1228-1237.

[12] J. Mićić, Y. SEO, S. E. TAKAhasi And M. TominaGa, Inequalities of Furuta and Mond-Pečarić, Math. Ineq. Appl., 2 (1999), 83-111.

[13] M. UchiYama, Operator monotone functions, positive definite kernels and majorization, Proc. Amer. Math. Soc., 138, 11 (2010), 3985-3996. 